\title{
Rozmowa Nowotworów z prof. Jackiem Fijuthem, Przewodniczącym Zarządu Głównego Polskiego Towarzystwa Onkologicznego
}

\author{
Nowotwory interview with Professor Jacek Fijuth President of the Polish Oncological Society
}

\begin{abstract}
Prof. Edward Towpik: Proszę Pana Profesora o przedstawienie wizji działania Zarządu Polskiego Towarzystwa Onkologicznego w kadencji 2014-18
\end{abstract}

Prof. Jacek Fijuth: Rozpoczęliśmy nową kadencję Zarządu Głównego Polskiego Towarzystwa Onkologicznego. Kierowanie największym i najstarszym, ale też najbardziej obecnie rozpoznawalnym towarzystwem onkologicznym w naszym kraju jest wielkim wyzwaniem. Tym bardziej, że przyszło nam działać w przełomowym momencie dla polskiej onkologii, okresie głębokich zmian orga-

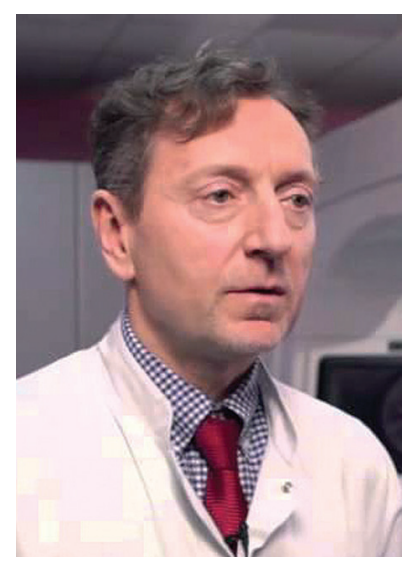

Prof. Jacek Fijuth celu kapitułę oceniło 15 zgłoszonych wniosków. Polska, z powodu niedostatku środków finansowych przeznaczanych na naukę, w wielu dziedzinach odstaje od wiodących ośrodków światowych, głównie w zakresie właśnie nauk podstawowych: biologii nowotworów, immunologii, biologii molekularnej. Chciałbym, aby tego typu konkursy grantowe, wspierające polskich naukowców, mogły być realizowane cyklicznie. Wymaga to jednak znaczącego zewnętrznego wsparcia finansowego. W tym miejscu chciałbym przypomnieć, że w ramach promocji nauki i jej pracowników Polskie Towarzystwo Onkologiczne funduje trzy nagrody stałe. Nagroda im. Hilarego Koprowskiego, prekursora logicznej. Wiele zapisów tak zwanych „ustaw pakietowych" zostało opracowanych, zgłoszonych bądź zaopiniowanych przez członków PTO.

Największym sukcesem poprzedniej kadencji było bez wątpienia przygotowanie Strategii Walki z Rakiem - pierwszego tego typu opracowania w Polsce powstałego poza administracją państwową. Dokument ten został złożony w Ministerstwie Zdrowia. Poprzez kontakty z wysokimi rangą pracownikami tego Ministerstwa, jak również pracownikami Ministerstwa Nauki, posłami i senatorami, zabiegamy o nadanie temu dokumentowi rangi oficjalnej. W dalszej perspektywie powinniśmy dopilnować realizacji zapisów Strategii w zakresie wszystkich trzydziestu opisanych celów tematycznych i publikować okresowe raporty z ich realizacji. Statutowym zadaniem Towarzystwa jest wspieranie działalności naukowej. Tę misję powinniśmy realizować przede wszystkim poprzez promocję nauk podstawowych i klinicznych, poprzez akcje stypendialne i grantowe, fundowanie nagród itp. Wiosną tego roku dzięki środkom otrzymanym od zewnętrznych instytucji przeprowadziliśmy konkurs na projekty w zakresie nauk podstawowych w onkologii. Kilkunastu recenzentów powołanych przez utworzoną w tym zastosowania przeciwciał monoklonalnych w onkologii, za cykl publikacji zrealizowanych w polskich ośrodkach, z dominującym udziałem polskich autorów. Nagroda im. Sobolewskich przyznawana jest polskim pracownikom naukowym za wybitne osiągnięcia w zakresie zwalczania chorób nowotworowych. Nagroda im. Franciszka Łukaszczyka jest przyznawana członkom Polskiego Towarzystwa Onkologicznego za oryginalne prace naukowe z dziedziny onkologii. Zapraszam do odwiedzenia strony internetowej PTO, gdzie zamieszczone są regulaminy nagród.

W nowej kadencji będziemy kontynuować współpracę z polskimi i zagranicznymi organizacjami naukowymi, rządowymi i pozarządowymi. Naszym pilnym zadaniem organizacyjnym będą działania na rzecz uchwalenia Il edycji Programu Zwalczania Chorób Nowotworowych - I edycja kończy się w 2015 r. W tym zakresie konieczne jest współdziałanie z administracją państwową i parlamentarzystami. Wielkim wyzwaniem będzie organizacja w październiku 2016 r. IV Kongresu Onkologii Polskiej, organizowanego w Łodzi. Liczę w tym zakresie na współpracę całego środowiska. Na członkach Zarządu Głównego spoczywają dodatkowe 
zadania. Profesor Radzisław Kordek jest Przewodniczącym Komitetu Naukowego, a ja — Przewodniczącym Komitetu Organizacyjnego Kongresu. Działa już komitet organizacyjny, tworzymy program naukowy. Chcielibyśmy, aby był wszechstronny, atrakcyjny i nowoczesny. Kongres organizuje kilkanaście towarzystw, które w spektrum działalności mają onkologię. Na sesjach będą omawiane zagadnienia kliniczne, teoretyczne, czy też zagadnienia z dziedzin nauk podstawowych w formie dyskusji wielodyscyplinarnej, tak by angażowały i diagnostów, i histopatologów, i klinicystów. W swoich działaniach będziemy wspierać merytorycznie i promować organ PTO — NOWOTWORY Journal of Oncology. Naszym wspólnym celem jest nadanie pismu jak najwyższej rangi naukowej, ale również zachowanie jego unikalnego charakteru — źródła informacji o teraźniejszości i historii polskiej onkologii.

Onkologia jest obecnie gorącym tematem. Chciałbym dokonać szerokiego otwarcia medialnego na jej problemy, uaktywnić media społecznościowe. Planujemy zaprosić do współpracy osoby powszechnie rozpoznawalne, aby były twarzą kampanii medialnych. Celem tych działań powinno być nakłonienie Polaków do zdrowego trybu życia, zdrowego odżywiania, niepalenia tytoniu, aktywności fizycznej, czyli do podstawowych postulatów onkologicznej profilaktyki pierwotnej. Nieustająco musimy propagować wykonywanie badań profilaktycznych, aby zmienić fatalnie niskie odsetki wykonywanych badań cytologicznych, mammograficznych, nie wspominając o endoskopii jelita grubego.

Pracujemy nad unowocześnieniem naszej strony internetowej na wzór najlepszych na świecie — np. Amerykańskiego Towarzystwa Onkologii Klinicznej. Planujemy stworzyć zintegrowany portal informacyjny dla pacjentów, wzorowany również na najlepszych przykładach: National Cancer Institute oraz American Society of Clinical Oncology. Szukamy środków i specjalistów, którzy nam w tym pomogą.

Musimy zmierzyć się też z realizacją „ustaw pakietowych” — poprzez swoich reprezentantów PTO będzie współdziałać z administracją rządową i samorządową nad wypełnieniem ich zapisów. Wielokrotnie deklarowaliśmy chęć współpracy z CMKP oraz Kolegium Lekarzy Rodzinnych w zakresie szkoleń, wsparcia merytorycznego i specjalistycznego dla lekarzy POZ.

Polska zajmuje w Europie drugą pozycję od końca w statystyce liczby onkologów przypadających na jednego miesz- kańca. W obliczu czekających nas wyzwań epidemiologicznych musimy to zmienić. We współdziałaniu z MZ i z CMKP zajmiemy się promocją specjalizacji onkologicznych wśród młodych medyków i zagwarantowaniem pełnego finansowania szkoleń specjalizacyjnych.

Uważam także za bardzo ważne wyrównanie poziomu szkolenia przeddyplomowego w polskich uczelniach medycznych. W tym zakresie jest wciąż wiele do zrobienia.

Obowiązkiem grupy wykonawczej Zarządu, głównie zaś moim, będzie opiniowanie rozporządzeń wykonawczych MZ i zarządzeń NFZ. W tym zakresie konieczna jest ścisła współpraca z innymi towarzystwami naukowymi, organizacjami lekarskimi, Naczelną Radą Lekarską oraz z organizacjami pacjentów onkologicznych — naszym ważnym partnerem.

Zależy mi bardzo na integracji środowiska. Nie chciałbym, aby wciąż były formułowane zarzuty jego rozbicia, istnienia podziałów i rozbieżnych interesów. W mojej, może trochę romantycznej koncepcji, konsolidacja środowiska byłaby powrotem „do źródel”, z PTO w roli organizacji-matki. Przecież wszystkie kliniczne towarzystwa onkologiczne wyłoniły się w przeszłości z Polskiego Towarzystwa Onkologicznego. Jest szansa, aby zrealizować ten zamysł. W ścisłym Zarządzie mamy dwóch wiceprezesów: prof. Piotra Rutkowskiego, prezesa Polskiego Towarzystwa Chirurgii Onkologicznej i prof. Piotra Wysockiego, prezesa-elekta Polskiego Towarzystwa Onkologii Klinicznej, a dodatkowo — w mojej osobie - wiceprezesa Polskiego Towarzystwa Radioterapii Onkologicznej. W ten sposób władze PTO skupiają "osobowo" 3 towarzystwa, z PTO jako czwartym. Wszystkie wymienione osoby deklarują wolę współpracy i podzielają pogląd, że tylko mówienie jednym głosem pozwoli usprawnić funkcjonowanie systemu leczenia onkologicznego w kraju.

Przed Zarządem Głównym PTO i osobiście przede mną jest ogrom pracy organicznej, nadzór nad strategią prowadzenia wszystkich wspomnianych wcześniej akcji, kontynuacja projektów rozpoczętych w poprzedniej kadencji. Czuję się odpowiedzialny za wypełnienie i powodzenie misji, jaka spoczywa na Zarządzie Towarzystwa w nowej kadencji. Misji, której celem jest przygotowanie polskiej onkologii do wyzwań XXI wieku.

Prof. ET: Dziękuję. 